\title{
HUBUNGAN SIKAP DAN PENGALAMAN PELAKSANAAN MANAJEMEN NYERI PADA PERAWAT TERHADAP PELAKSANAAN MANAJEMEN NYERI PASIEN PASCA OPERASI
}

\author{
Bella Arinda Mashita Dewi*, Chandra Bagus Ropyanto** \\ *Mahasiswa Jurusan Keperawatan Fakultas Kedokteran Universitas Diponegoro \\ **Dosen Jurusan Keperawatan Fakultas Kedokteran Universitas Diponegoro \\ E-mail : chandra_undip@yahoo.com
}

\begin{abstract}
ABSTRAK
The Ameican Society of Anastheiologists (ASA) mendefiniskan nyeri pasca operasi sebagai nyeri yang timbul pada pasien karena prosedur bedah yang dilakukan. Nyeri pasca operasi yaang tidak ditangani dapat berefk secara fisiologis dan psikologis pada pasien. Manajemen nyeri penting untuk mengurangi nyeri dan memberikan kenyamanan pada pasien sehingga peningkatan manajemen nyeri merupakan kebutuhan mendesak. Faktor yang mempengaruhi perawat pada pelaksanaan manajemen nyeri yaitu sikap dan pengalaman perawat. Penelitian bertujuan mengidentifikasi hubungan sikap dan pengalaman terhadap pelaksanaa manajemen nyeri. Desain penelitian adalah kuantitatif korelasi dengan pendekatan cross sectional dengan sampel non probability sampling berupa tehnik total sampling dan jumlah responden 45 perawat di ruang perawatan bedah. Hasil penelitian didapatkan perawat dengan sikap positif sebnyak $62,2 \%$ dengan pengalaman kurang sebanyak 55,6 \%, dan manajemen nyeri kurang baik $51,1 \%$. Hasil uji statistik didapakan nilai $\mathrm{p}=0,003$ sehingga didapatkan hubungan antara sikap terhadap pelaksanaan manajemen nyeri. Terdapat hubungan antara pengalaman terhadap manajemen nyeri dengan nilai $\mathrm{p}=0,025$. Hasil penelitian dapat digunakan sebagai bahan kajian untuk pelaksanaan manajemen nyeri dengan menambah wawasan perawat, sementara sikap positif perawat harus dipertahankan dan menambajh pengalaman perawat dengan memberikan pelatihan serta seminar tentang manajemen nyeri.
\end{abstract}

Kata kunci :

Manajemen nyeri, sikap perawat, pengalaman perawat. 


\section{PENDAHULUAN}

The American Society of Anestesiologists (ASA) mendefinisikan nyeri pasca operasi sebagai nyeri yang timbul pada pasien pasca bedah karena prosedur bedah yang dilakukan (Abdalrahim, 2009). Nyeri pasca operasi merupakan hal yang fisiologis tetapi merupakan salah satu keluhan yang ditakuti klien setelah pembedahan. Nyeri pasca operasi yang tidak terkontrol dapat memberikan efek secara fisiologis dan psikologis pasien (Smeltzer, 2002). Penelitian sebelumnya melaporkan bahwa nyeri pasien yang mengalami bedah laparatomy tidak ditangani secara adekuat oleh tenaga kesehatan (Haeruddin, 2013). Perawat memiliki peran penting dalam pelaksanaan manajemen nyeri karena nyeri yang terjadi pada klien harus menjadi perhatian perawat. Membiarkan pasien sakit tanpa upaya dalam memberikan perawatan yang optimal merupakan hal yang sangat tidak etis (Potter, 2006). Manajemen nyeri adalah upaya mengurangi rasa sakit sampai pada tingkat kenyamanan yang dapat diterima pasien (NIC, 2012). Manajemen nyeri yang efektif adalah aspek penting asuhan keperawatan untuk proses penyembuhan, pencegahan komplikasi, mengurangi penderitaan dan mencegah perkembangan nyeri yang tidak dapat disembuhkan. Pelaksanaan manajemen nyeri saat ini belum dilakukan secara maksimal oleh tenaga kesehatan terutama perawat (Kipkorir, 2011).

Faktor-faktor yang mempengaruhi manajemen nyeri adalah pengetahuan, sikap, pengalaman, dan standar yang ada (Potter, 2001). Penelitian sebelumnya menyatakan bahwa perawat onkologi memiliki skor yang lebih tinggi dala memiliki pengetahuan dan sikap positif terhadap nyeri dibandingkan dengan perawat non-onkologi Perawat memiliki sikap positif karena perawat telah memiliki pendidikan tambahan mengenai manajemen nyeri (El-Rahman, 2013). Sikap adalah faktor penentu perilaku, sehingga sikap dapat mempengaruhi pelaksanaan manajemen nyeri (Wawan, 2010). Pengalaman merupakan faktor yang paling berpengaruh yang mempromosikan pengetahuan perawat dan keyainan mengelola pasien. Pengalaman didapat dari lama kerja, pelatihan, seminar, dan pengalaman sebelumnya dalam mengelola pasien (El-Rahman, 2013). Penelitian ini bertujuan fraktur mengetahui hubungan antara sikap dan pengalaman perawat terhadap pelaksanaan manajemen nyeri pasca operasi.

\section{METODE PENELITIAN}

Jenis penelitian adalah kiantitaatif non eksperimental dengan desain penlitian analitik korelasi dan pendekatan cross-sectional. Tehnik sampling yang digunakan adalah nonprobability sampling dengan jenis pengambilan sampel menggunakan sampel jenuh (total sampling). 
Penelitian dilakukan terhadap 45 responden perawat yang bekerja diruang perawatan bedah. Instrumen penelitian yang digunakan berupa kuisioner yang terdiri dari kuisioner sikap, pengalaman, dan manajemen nyeri. Kuisioner sikap terdiri dari 17 item pertanyaan dengan rentang nilai uji validitas $r=0,384-0,904$ dan nilai reliabilitasnya 0,939 . Kuisioner pelaksanaan manajemen nyeri terdiri dari 30 item dengan nilai $r=0,101-0,872$ dan nilai reliabilitas 0,949 . Terdapat pertanyaan dengan nilai $r<0,381$ tetapi tetap digunakan karena termasuk pertanyaan vital dan penting dengan dirubah redaksi kalimatnya sebelum digunakan dalam penelitian

\section{HASIL PENELITIAN DAN PEMBAHASAN}

Hasil analisis pada tabel 1 menunjukan bahwa hampir seluruhnya responden berjenis kelamin perempuan sebanyak 28 responden $(62,2 \%)$. Usia responden paling banyak adalah dewasa awal (26-35 tahun) sebanyak 27 responden $(60,0 \%)$.

Tabel 1. Distribusi karakteristik responden di RSUD Dr. Adhyatmma MPH Kota Semarang tahun $2014(n=45)$

\begin{tabular}{lcc}
\multicolumn{1}{c}{ Karakteristik Responden } & Frekuensi & \% \\
\hline Jenis Kelamin & & \\
Laki-laki & 17 & 37,8 \\
Perempuan & 28 & 62,2 \\
\hline Total & 45 & 100 \\
\hline Usia & & \\
Remaja akhir (17-25 tahun) & 12 & 26,7 \\
Dewasa awal (26-35 tahun) & 5 & 60 \\
Dewasa akhir (36-45 tahun) & 3 & 13,3 \\
\hline Total & 45 & 100 \\
\hline
\end{tabular}

Sebagian besar perawat berjenis kelamin perempuan dan sebagian besar berada pada kategori usia dewasa awal. Jenis kelamin dan usia merupakan faktor internal dari terbentuknya suatu perilaku seseorang. Perilaku seorang perempuan akan berdasarkan pertimbangan emosional atau perasaan, sehingga mempengaruhi sikap. Masa dewasa awal merupakan suatu masa atau periode penyesuaian diri terhadap pola-pola kehidupan yang baru dan harapan-harapan sosial baru. Masa dewasa awal merupakan masa seseorang mencapai kedewasaan dalam arti sesungguhnya, sebagai hasil belajar dan pengalaman. Menurut Hurlock semakin cukup umur, tingkat kematangan dan kekuatan seseorang akan lebih matang dalam berpikir dan bekerja yang dapat dilihat dari pengalaman dan kematangan jiwa. Perawat pada usia dewasa awal akan dapat lebih menerima hal-hal baru yang didapatkan serta dipadukan dengan proses belajar dan pengalaman yang dimilikinya. Proses tersebut akan menjadi keyakinan serta membentuk pola sikap yang dianggapnya benar (Desmita, 2007).

Dewi / Hubungan sikap dan pengalaman pelaksanaan manajemen nyeri...Page 39 of 43 
Tabel 2 menunjukan bahwa sikap perawat sebagian besar positif sebanyak 28 responden $(62,2$ $\%)$. Pengalaman perawat lebih dari setengah termasuk kategori kurang sebanyak 25 responden $(55,6 \%)$. Pelaksanaan manajemen nyeri pasca operasi lebih dari setengahnya baik sebanyak 23 responden $(51,1 \%)$.

Tabel 2. Distribusi Frekuensi Perawat Berdasarkan Sikap, Pengalaman, dan Manajemen Nyeri di RSUD Dr, Adhyatma MPH Kota Semarang $(n=45)$

\begin{tabular}{|c|c|c|c|}
\hline No & Kategori & $\mathbf{F}$ & $\%$ \\
\hline \multirow[t]{4}{*}{1.} & Sikap Perawat & & \\
\hline & a. Positif & 28 & 62,2 \\
\hline & b. Negatif & 17 & 37,8 \\
\hline & Total & 45 & 100 \\
\hline \multirow[t]{4}{*}{2.} & Pengalaman & & \\
\hline & a. Baik & 20 & 44,4 \\
\hline & b. Kurang & 25 & 55,6 \\
\hline & Total & 45 & 100 \\
\hline \multirow[t]{4}{*}{3.} & Manajemen Nyeri & & \\
\hline & a. Baik & 22 & 48,9 \\
\hline & b. Kurang & 23 & 51,1 \\
\hline & Total & 45 & 100 \\
\hline
\end{tabular}

Sebagian besar repsonden memiliki sikap positif terhadap manajemen nyeri pasca operasi. Sikap positif yang dimiliki perawat perlu dimanifestasikan dalam bentuk tanggapan atau respon perasaan positif perawat terhadap nyeri yang dikeluhkan pasien dan hal tersebut membantu dalam pelaksanaan manajemen nyeri. Pendidikan tambahan mengenai manajemen nyeri juga dapat membentuk sikap perawat lebih positif. Sikap positif didukung dari analisis item pertanyaan pada aspek penggunaan terapi farmakologis dan non-farmakologis dimana sebagian besar perawat menjawab setuju. Perawat penting memberi dan memantau terapi yang diprogamkan dokter untuk penghilang rasa nyeri (tindakan farmakologis) dan penggunaan tindakan penghilang rasa nyeri yang mandiri sehingga melengkapi terapi yang diprogramkan dokter. Penggunaan kombinasi terapi penting untuk membantu pasien mengatasi nyeri yang dialami (Prasetyo, 2010). Pengkajian nyeri dari efek samping medikasi sebagian besar perawat menjawab setuju. Peran perawat dalam medikasi bahwa perawat perlu melakukan pengkajian efektivitas obat yang diberikan dan melihat efek samping obat dalam mengurangi nyeri pasien. Sebagian besar perawat memiliki pengalaman kurang terhadap manajemen nyeri pasca operasi. Pengalaman merupakan proses pembentukan pengetahuan atau ketrampilan tentang suatu pekerjaan yang dilakukan sehari-hari (Manulang, 1984). Pengalaman kurang dapat dilihat pada aspek pengalaman kerja perawat, dimana sebagian besar perawat bekerja selama 0-5 tahun dan kurang dari dua tahun di ruang perawatan bedah. Pengalaman kurang pada responden juga

Dewi / Hubungan sikap dan pengalaman pelaksanaan manajemen nyeri...Page $\mathbf{4 0}$ of $\mathbf{4 3}$ 
dilihat pada aspek pendidikan perawat, dimana sebagian besar tingkat pendidikan responden adalah diplomat keperawatan. Pengalaman perawat didapat dari pendidikan akademis dan pengalaman praktik yang saling memperkuat satu sama lain. Perawat dapat menambah pengalaman dengan mengikuti seminar, membaca jurnal, atau artikel tentang nyeri dan manajemen nyeri yang tepat, pengalaman sebelumnya dalam manajemen nyeri, efek dari pengalaman bekerja sebagai perawat (Stanley, 2013). Pengalaman kurang juga dapat dilihat pada aspek pelatihan, dimana sebagian besar perawat tidak mengikuti pelatihan saat bekerja. Pelaksanaan manajemen nyeri tidak lepas dari faktor sikap, pengalaman, dan faktor lain yang mempengaruhi. Sebagaian besar perawat melaksanakan manajemen nyeri pasca operasi kurang baik. Manajemen nyeri yang efektif belum tercapai karena berbagai hambatan antara lain kurangnya pengetahuan, prinsip pribadi, perasaan yang dipengaruhi orang lain, kemampuan untuk menilai nyeri, pengambilan keputusan, dan penggunaan informasi berbasis jurnal untuk manajemen nyeri dan pertimbangan nyeri yang buruk (Kipkorir, 2011). Faktor lain diluar perawat yang mempengaruhi manajemen nyeri yang kurang baik salah satunya sarana dan prasarana serta kebijakan dari rumah sakit sendiri (Moenir, 2000).

Hasil penelitian menunjukan bahwa terdapat hubungan antara sikap perawat terhadap pelaksanaan manajemen nyeri pasca operasi. Sebagian besar perawat yang memiliki sikap positif sudah menerapkan pelaksanaan manajemen nyeri dengan baik. Hasil penelitian sesuai dengan teori yang menyatakan bahwa sikap merupakan faktor yang mempengaruhi perilaku seseorang. Responden yang mempunyai sikap positif seharusnya dapat bersikap baik, tetapi terdapat responden dengan sikap positif dengan pelaksanaan manajemen nyeri kurang. Pelaksanaan manajemen nyeri yang kurang dipengaruhi oleh faktor lain seperti pengetahuan yang kurang. Penelitian sebelumnya menyatakan bahwa perawat onkologi telah mempunyai sikap yang positif karena sebagian besar perawat onkologi telah mendapatkan persiapan pendidikan tambahan untuk manajemen nyeri farmakologis atau non-farmakologis. Penelitian tersebut juga menjelaskan bahwa sikap perawat dalam manajemen nyeri lebih baik pada perawat onkologi karena telah memiliki pendidikan khusus tentang manajemen nyeri (Kipkorir, 2011).

Tabel 3 menunjukan bahwa perawat yang memiliki sikap positif sebanyak 28 perawat dimana 67,9\% atau 19 perawat memiliki sikap positif. Hasil analisa hubungan menunjukan bahwa terdapat hubungan antara sikap perawat dengan pelaksanaan manajemen nyeri dengan nilai $\mathrm{p}=0,003$. Perawat yang memiliki pengalaman kurang sebanyak 25 orang, ternyata $68 \%$ atau 
17 perawat pelaksanaan manajemen nyeri termasuk kurang. Hasil analisa hubungan menunjukan bahwa terdapat hubungan antara pengalaman dengan manajemen nyeri pasca operasi dengan nilai $\mathrm{p}=0,025$.

Tabel 3. Hubungan antara sikap perawat dengan pelaksanaan manajemen nyeri

\begin{tabular}{|c|c|c|c|c|c|}
\hline \multirow[b]{2}{*}{ Sikap Perawat } & & \multicolumn{2}{|c|}{ Pelaksanaan Manajemen Nyeri Pasca Operasi } & \multirow[t]{2}{*}{ Total } & \multirow[t]{2}{*}{ Nilai $\mathrm{p}$} \\
\hline & & Baik & Kurang & & \\
\hline & Positif & $19(67,9 \%)$ & $9(32,1 \%)$ & $28(100 \%)$ & 0,003 \\
\hline & Negatif & $3(17,6 \%)$ & $14(82,4 \%)$ & $17(100 \%)$ & \\
\hline & Total & $22(48,9 \%)$ & $14(51,1 \%)$ & $45(100 \%)$ & \\
\hline \multirow{4}{*}{$\begin{array}{c}\text { Pengalaman } \\
\text { Perawat }\end{array}$} & & Baik & Kurang & & \\
\hline & $\overline{\text { Baik }}$ & $14(70 \%)$ & $6(30,0 \%)$ & $20(100 \%)$ & 0,025 \\
\hline & Kurang & $8(32 \%)$ & $17(68,0 \%)$ & $25(100 \%)$ & \\
\hline & $\overline{\text { Total }}$ & $22(48,9 \%)$ & $23(51,1 \%)$ & $45(100 \%)$ & \\
\hline
\end{tabular}

Hasil penelitian ini juga menunjukan bahwa ada hubungan antara pengalaman perawat terhadap pelaksanaan manajemen nyeri pasca operasi. Pengalaman seseorang dapat mempengaruhi dalam berperilaku. Pada penelitian ini menunjukan bahwa pengalaman yang kurang akan menghasilkan pelaksanaan manajemen nyeri yang kurang juga. Hal ini dapat dipengaruhi faktor seperti tingkat pendidikan dan pengetahuan yang dimiliki. Penelitian sebelumnya melaporkan bahwa pengalaman perawat memiliki hubungan terhadap pelaksanaan manajemen nyeri pada anak-anak. Pengalaman yang diperoleh perawat melalui pendidikan, pelaksanaan tugas pekerjaan, media informasi, seminar, pergaulan, dan pengamatan. Pengalaman didapat dari pengetahuan dan pelatihan yang disebut sebagai keahlian klinis. Hal ini dapat dapat dipengaruhi oleh waktu yang dihabiskan perawat dalam bidang kerja mereka, memperbaharui pengetahuan yang dimiliki dengan penelitian membaca jurnal penelitian mengenai manajemen nyeri serta pembelajaran akademik yang diperoleh selama masa sekolah keperawatan (Stanley, 2013). Pengalaman akademis dan pengalaman praktik harus saling memperkuat satu sama lain yang akan membentuk pengalaman baik. Pengalaman baik tersebut akan membantu perawat dalam melaksanakan manajemen nyeri yang efektif.

\section{KESIMPULAN}

Sikap perawat sebagian besar memiliki sikap positif, perawat memiliki pengalaman kurang serta pelaksanaan manajemen nyeri pasca nyeri kurang baik. Terdapat hubungan antara sikap perawat terhadap pelaksanaan manajemen nyeri pasca nyeri, serta terdapat hubungan antara pengalaman perawat terhadap pelaksanaan manajemen nyeri pasca operasi. 
Hasil penelitian dapat digunakan sebagai kajian bagi rumah sakit untuk meningkatkan pelaksanaan manajemen nyeri serta meningkatkan pengetahuan bagi perawat melalui kegiatan pelatihan, seminar, dan memperbaharui pengetahuan.

Penelitian lebih lanjut dilakukan dengan mengidentifikasi faktor lain yang berpengaruh seperti karakteristik responden, pengetahuan, dan keyakinan diri.

\section{DAFTAR PUSTAKA}

Abdalrahim, M.S. (2009). Postoperative Pain Assesment and Management The Effect of Educational Program on Jordanian Nurses' Practice, Knowledge, and Attitudes. Diakses : https://gupea.ub.gu.se/bitstream/2077/20316/4/gupea_2077_20136_4.pdf

Bulechek, G.M. \& Docther, J.M.C. (2007). Nursing Intervention Classification (NIC). Philadelphia : Mosby Elsevier.

Desmita. (2008). Psikologi Perkembangan. Bandung : Remaja Rosdakarya.

El-Rahman, M.A. et al (2013). Knowledges and Attitude Towards Pain Management, A Comparassion between Oncology and Non-Oncology Nurses in Jordan. International Journal of Advanced Nursing Studies. Diakses dari http://www.sciencepubco.com/index.php/IJANS/article/view/1006.

Haeruddin, H., \& Ahmad, M.R.Dahlen, L., Zimmerman, L., \& Barron, C. (2006). Pain perception and its relation to functional status post total knee arthroplasty : a pilot study. Orthopaedic Nursing, July-August 2006, 25 (4). Academic Research Library.

Kipkorir, C. (2012). Knowledge and Attitudes of Nurses Towards Pain Management among The Elderly: A Case study of registered nurses from the local healthcare centers kokkola. Central Ostrobothnia University of Applied Sciences. Diakses dari : https://www.theseus.fi/bitstream/handle/10024/39296/Christopher_Kipkorir.pdf.

Manulang. (1984). Manajemen Personalia. Jakarta : Ghalia Indonesia.

Moenir, H.A.S. (2000). Manajemen Pelayanan Umum di Indonesia. Jakarta : Bumi Aksara.

Potter, P.A., \& Perry, A.G. (2001). Fundamental Of Nursing 6th edition. Australia, ElseiverMosby.

Potter, P.A., \& Perry, A.G. (2006). Buku Ajar Fundemental Keperawatan : Konsep, proses, dan Praktik. Jakarta, EGC.

Prasetyo, S.N. (2010). Konsep dan Proses Keperawatan Nyeri. Yogyakarta, Graha Ilmu.

Smeltzer, S.C. (2002). Buku Ajar Keperawatan Medikal Bedah : Brunner \& Suddarth. Jakarta, EGC.

Stanley, M. \& Pollard, D. (2013). Relationship between Knowledge, Attitudes, and Self Efficacy of Nurses in The Management of Pediathric Pain. Contuining Nursing Education, Vol. 39. 20.

Wawan, S. \& Dewi, M. (2010). Teori dan Pengukuran Pengetahuan, Sikap, dan Perilaku Manusia. Yogyakarta, Nuha Medika 